\title{
PEMBUATAN GAME BERBASIS PEMBELAJARAN MENGGUNAKAN RPG MAKER MV
}

\author{
Sri Ngudi Wahyuni ${ }^{1}$ and Cia Andiyoko ${ }^{2}$ \\ ${ }^{1}$ Manajemen Informatika, \\ ${ }^{2}$ Informatika, \\ ${ }^{1,2}$ Universitas Amikom Yogyakarta, Jl. Ring Road Utara, Depok, Sleman, Yogyakarta, \\ 55281, Indonesia \\ yuni@amikom.ac.id ${ }^{l}$, ciaandiyoko@gmail.com²
}

\begin{abstract}
The RPG game is one of the games are in great demand by the public because they are able to sharpen their right brain. One method used in game development is GDLC which consists of 6 phases, where each phase is arranged systematically. The aimed of this study is how to develop RPG maker game based learning for children cognitive. The analysis method is used SWOT analysis and testing method used a and $\beta$ testing methods on 36 respondents who were taken by random and the response rate was $99.8 \%$. The testing instrument used a questionnaire with testing parameters (1) Design consisting of music, sound, and color (2) Moral Message (3) Storyline. The test of results were 42.5\% of respondents said that the development design was considered good, 44.3\% of respondents said the game had a good storyline, and $56.3 \%$ of respondents stated that the Rise of the Zokai Clan game using RPG Maker MV had a good moral message.
\end{abstract}

Keywords: Games, RPG Maker MV, GDLC.

\begin{abstract}
ABSTRAK
Game RPG merupakan salah satu game yang sangat diminati masyarakat karena mampu mengasah otak kanan penggunanya. Salah satu metode yang digunakan dalam pengembangan game adalah GDLC yang terdiri dari 6 fase, dimana setiap fasenya disusun secara sistematik. Tujuan penelitian ini adalah bagaimana membangun game RPG maker berbasis pembelajaran kognitif bagi anak-anak. Metode analisis yang digunakan adalah analisis SWOT dengan metode pengujian a testing dan $\beta$ testimeghadap 36 responden yang diambil secara acak dan respon rate sebesar 99.8\%. Instrumen pengujian yang digunakan adalah kuesioner dengan parameter pengujian (1) Desain yang terdiri dari musik, suara, dan warna (2) Pesan Moral (3) Alur Cerita. Adapun hasil pengujiannya adalah 42.5\% responden menyatakan bahwa desain pengembangan dianggap baik, $44.3 \%$ responden menyatakan game memiliki alur cerita yang baik, dan 56.3\% responden menyatakan bahwa game Rise of The Zokai Clan menggunakan RPG Maker MV ini memiliki pesan moral yang baik.
\end{abstract}

Kata Kunci: Games, RPG Maker MV, GDLC.

\section{PENDAHULUAN}

Game merupakan salah satu sarana hiburan yang banyak diminati banyak orang [1]. Perkembangan game di Indonesia semakin meningkat setiap tahunnya. Game digunakan untuk mengisi waktu luang, refreshing, dan bermain bersama teman. Game yang dimainkan juga dapat berbagai macam platform, mulai dari mobile, desktop, website, bahkan juga bisa dimainkan secara online maupun offline. Saat ini game yang banyak dikembangkan dalam PC / Personal Computer karena merupakan platform paling kuat, kelebihannya karena PC memiliki daya spesifikasi paling tinggi, semakin murah dan terjangkau oleh masyarakat luas. Salah satu game yang paling diminati adalah game RPG. Role
Playing Game atau RPG adalah sebuah permainan yang pemerannya memerankan tokoh-tokoh khayalan dan berkolaborasi untuk merangkai cerita bersama. Para pemain game tersebut memilih aksi tokoh-tokoh berdasarkan karakteristik tokoh tersebut, dan keberhasilan aksinya tergantung dari sistem peraturan yang telah ditentukan dan pemain bisa berimprovisasi membentuk arah dan hasil permainan [2]. Salah satu game yang diteliti oleh Saputra (2015) adalah game yang berbasis personal computer [3]. Sedangkan Wardhana (2015) membangun game yang beradaptasi pada serial kartun tahun 70an [4].

RPG Maker MV adalah sebuah program yang memungkinkan pengguna untuk membangun 
game berjenis RPG dengan kreasi sendiri. Program ini berperan cukup baik sebagai sebuah mesin pengedit RPG, dimana game RPG ini dapat dimainkan secara langsung tanpa menambahkan program lain. Permasalahan yang terjadi saat ini adalah game yang beredar lebih berfokus pada kualitas grafis tinggi, adegan action, dan hanya untuk menarik minat pembeli. Developer game lebih berfokus pada pengembangan game yang diminati masyarakat tanpa memperhatikan konten game yang memberi pengaruh buruk bagi pemain. Berdasarkan beberapa uraian diatas maka tujuan penelitian ini adalah bagaimana membangun game berbasis pembelajaran kognitif.

\section{METODE PENELITIAN}

Tahapan yang dilakukan pada pada penelitian ini dapat dilihat pada Gambar 1.

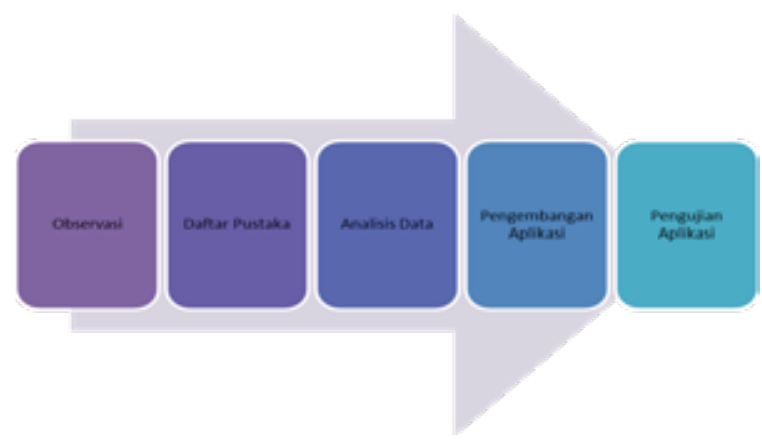

Gambar 1. Tahapan penelitian.

Gambar 1. Menjelaskan tentang tahapan penelitian dalam pengembangan game berbasis pembelajaran. Adapun tahapan penelitian yang dilakukan adalah:

\ Tahap 1 adalah proses observasi.

Proses observasi adalah proses melakukan ujicoba dengan memainkan beberapa game yang serupa dan mengamati beberapa parameter, yaitu jalannya game, warna game, dan pesan moral yang ada didalam game-game tersebut.

\ Tahap 2, adalah membaca beberapa referensi tetang game berbasis pembelajaran dengan kriteria dan parameter jalannya game, warna game, dan pesan moral yang ada didalam gamegame tersebut.

\ Tahap 3, adalah tahap melakukan analisis data. Analisis data dilakukan dengan menggunakan analisis SWOT. Analisis SWOT adalah metode perencanaan strategis yang digunakan untuk mengevaluasi kekuatan (Strenght), kelemahan (Weakness), peluang (Opportunities), dan ancaman (threats) dalam suatu proyek atau suatu spekulasi bisnis [6]. Keempat faktor itulah yang membentuk akronim SWOT (Strenght, Weakness, Opportunities, dan Threats). Proses ini melibatkan penentuan tujuan yang spesifik dari spekulasi bisnis atau proyek dan mengidentifikasi faktor internal dan eksternal yang mendukung dan yang tidak mendukung.melalui beberapa langkah. Adapun hasilnya adalah:

\section{Strenght}

Merupakan kondisi kekuatan yang terdapat dalam suatu produk. Kekuatan yang dianalisis merupakan faktor yang terdapat di dalam produk itu sendiri. Game RPG Maker Kaneki; Rise of The Zokai Clan ini memiliki kekuatan sebagai berikut:

a. Game ini membantu dalam melatih daya ingat, karena dalam permainan ini menuntut user untuk berkonsentrasi melewati rintangan yang ada.

b.Menggunakan bahasa yang ringan/yang digunakan sehari-hari.

c. Alur cerita ga klise atau gampang ditebak.

d.Bisa dimainkan oleh semua umur.

\section{Weakness}

Kelemahan yang dianalisis berdasarkan faktor kekurangan yang terdapat dalam Game RPG ini. Kelemahan yang terdapat dalam aplikasi game ini antara lain:

a. Tidak semua anak bisa mengoperasikan komputer.

b. Di grafik yang masih menggunakan 2 dimensi

c. Implementasi model permainan hampir sama dengan permainan RPG lain secara umum.

\section{Opportunities}

Beberapa peluang yang dapat dimanfaatkan untuk mengembangkan dan memasarkan game ini antara lain:

a. Fitur dan teknologi kemampuan software yang berkembang mendukung hasil yang lebih baik.

b. Komputer di era modern ini yang sudah menjadi pengetahuan umum.

c. Anak-anak sekarang lebih menyukai game komputer.

d. Game ini mengandung pesan moral yang baik

e. Minimnya pesaing jika ingin dipasarkan.

\section{Threat}

Ancaman utama yang patut diperhitungkan dalam pengembangan game ini adalah:

a. Penyebaran informasi yang cepat dan bebas sehingga mudah terjadi pembajakan atau plagiatisme.

b. Game lain yang lebih menarik tanpa ada unsur pesan moral didalamnya

c. Game bergenre RPG seperti ini kurang banyak peminatnya.

\ Tahap 4, adalah tahapan pengembangan game. Metode pengembangan game pada penelitian ini 
menggunakan framework Game Development Life Cycle (GDLC). Metode pengembangan ini terdiri dari beberapa tahapan secara sistematis dengan 6 fase utama yaitu Inisialisasi, PraProduksi, Produksi, Testing (Pengujian), Rilis versi Beta dan Rilis versi lengkap.

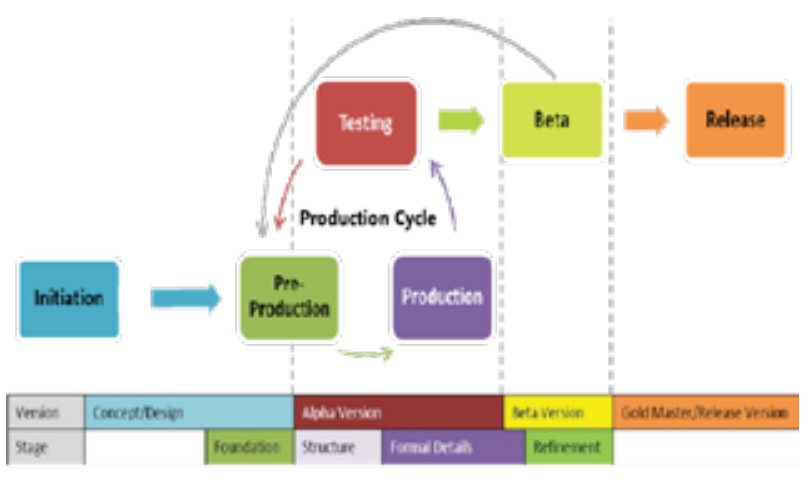

Gambar 2. Model GDLC

Adapun tahapan pada GDLC menurut McGrath (2011) adalah terdiri dari empat proses antara lain:

1. Tahapan Perancangan Syarat-syarat. Pada tahapan ini pengguna merumuskan ide apa yang harus difiturkan oleh game tersebut.

2. Tahapan Perancangan Penggunaan. Pada tahapan ini dilakukan perancangan proses dan perancangan interface dari game tersebut. pembuatan dan penyesuaian terhadap rancangan-rancangan yang telah didefinisikan.

3. Fase Konstruksi. Pada tahapan ini dilakukan pembuatan dan penyesuaian terhadap rancangan-rancangan yang telah didefinisikan.

4. Fase Pelaksanaan. Pada tahapan ini dilakukan pengujian dan analisis terhadap game yang dibuat dengan menggunakan RPG Maker MV.

Tetapi rangkaian GDLC terkadang disederhanakan menjadi 3 fase utama yaitu Idea/Concept, Development, dan Deployment.

\section{Idea/Concept}

Proses yang dilakukan pada fase ini adalah, merumuskan ide-ide dasar terkait latar belakang pembangunan sebuah game, kemudian membuat cerita utama, spesifikasi karakter, genre game, jenis art yang digunakan, platform yang akan dituju, dimensi game yang akan dibuat.

\section{Development}

Proses yang dilakukan pada fase development adalah merancang dan membangun game dari fase sebelumnya yaitu fase idea/concept kemudia di uji coba serta merumusan yang lebih tertuju pada penetapan jadwal pengembangan game, penentuan Tim yang terlibat serta tenggat waktu yang akan digunakan dalam fase pembangunan yang sudah memasukkan unsur pengujian dan penetapan tanggal rilis beta.

\section{Deployment}

Proses yang dilakukan pada fase Deployment adalah teknis publikasi game pada platform yang dituju, termasuk skema persiapan patch jika game yang dihasilkan memiliki bug atau mengalami gangguan teknis terkait perbedaan environment platform yang dituju. Fase development merupakan fase yang paling penting karena seluruh hasil perancangan, uji coba analisis pada GDD Akan diterjemahkan ke dalam bentuk program/aplikasi game menggunakan Game Engine yang mengenkapsulasi dua fungsi dasar yang berkaitan dengan Asset (gambar, suara, dan film) dan Logic (fungsi-fungsi interaksi).

\ Tahap 5, adalah tahapan pengujian. Teknik pengujian aplikasi game ini menggunakan Tahap akhir pengembangan adalah pengujian. Pengujian yang dilakukan pada penelitian ini adalah a testing dan $\beta$ testing. Pengujian a testing dilakukan dengan metode white box dan black box tes, sedangkan $\beta$ testing dilakukan dengan menggunakan metode random sampling terhadap beberapa responden.

Adapun instrument pengujian adalah pertanyaan atau kuisioner (Rais, 2017). Sebagai berikut:

(1) Desain yang terdiri dari musik, suara, dan warna.

(2) Pesan Moral yang disampaikan oleh game.

(3) Alur Cerita, apakah mudah dipahami atau tidak.

Pengujian ini dilakukan untuk mengukur kelayakan game yang telah dikembangkan. Adapun teknik ujinya adalah dengan random sampling terhadap 36 responden, dan data diolah menggunakan SPSS.

Adapun teknik pengolahan data menggunakan analisis frekuensi. Adapun rumus analisis frekuensi ditunjukkan pada rumus dibawah ini.

$$
f=\frac{x}{n} x 100 \%
$$
Dimana:
$\mathrm{f}=$ Prosentase
$\mathrm{x} \quad$ = Jumlah yang didapat
$\mathrm{n} \quad=$ Jumlah responden 


\section{III.ANALISA}

Game ini dibuat untuk dimainkan pada Personal Computer dengan sistem operasi windows dan bersifat single player sehingga hanya dapat dimainkan oleh satu pemain. Adapun langkah permainan dapat dilihat pada gambar 3 dibawah ini.

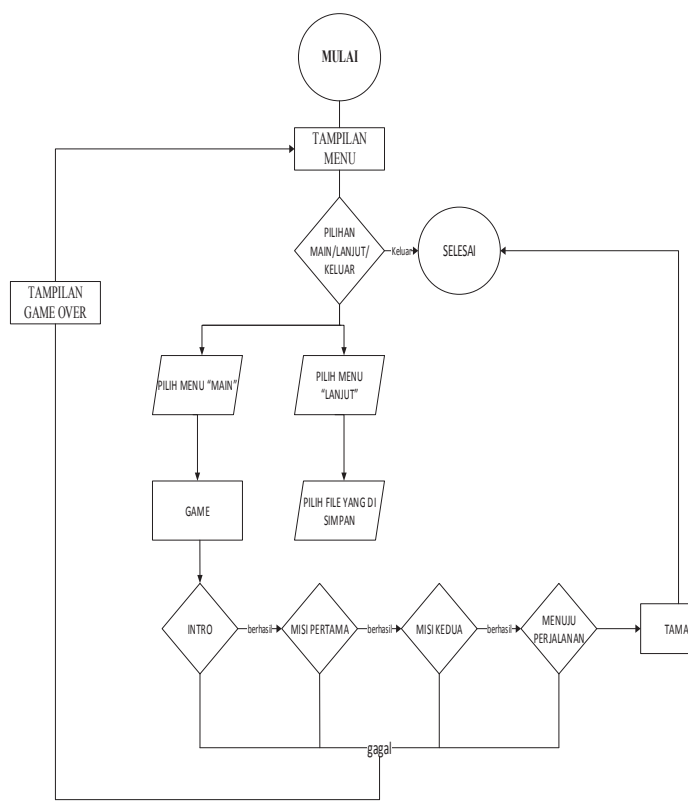

Gambar 3. Flowchart Game

Gambar 3. Menjelaskan tentang alur permainan game, yaitu:

1. Memulai game dengan tampilan awal menu yang berisikan Main, Lanjut, Petunjuk, Keluar. Jika keluar maka permainan selesai.

2. Jika pilih menu Main, maka permainan dimulai dengan hasil akhir, dan pemain tidak dapat melewati intro misi pertama dan kedua.

3. Jika pemain utama melewati perjalanan maka tampilan tamat dan permainan selesai.

4. Jika pilih menu Lanjut, maka pilih file yang sudah tersimpan dan melanjutkan hingga pemain utama ini mati atau menyelesaikan permainan.

\section{Perancangan Karakter, Sprite dan Map}

Desain karakter dan sprite dibuat dengan menggunakan tool character generator yang merupakan fitur RPG Maker MV. Dari tool tersebut Akan diekspor hasil desain karakter ke dalam foder game sehingga dapat digunakan pada saat pembuatan game. Namun pengguna juga bisa menggunakan desain bawaam (default) jika memang desain tersebut jika dirasa sudah cukup baik dalam pembuatan game. Adapun perancangan karakter dapat dilihat pada gambar 4 . Pada gambar 4. Menunjukkan beberapa karakter yang digunakan pada game berbasis pembelajaran ini. Terdapat 8 karakter utama yang dimainkan pada game ini dan rancangan karakter yang dibangun sejumlah 8 orang dengan memiliki warna dan dominasi karakter yang berbeda-beda. Karakter ini dimainkan pada level permainan dan misi yang berbeda-beda.

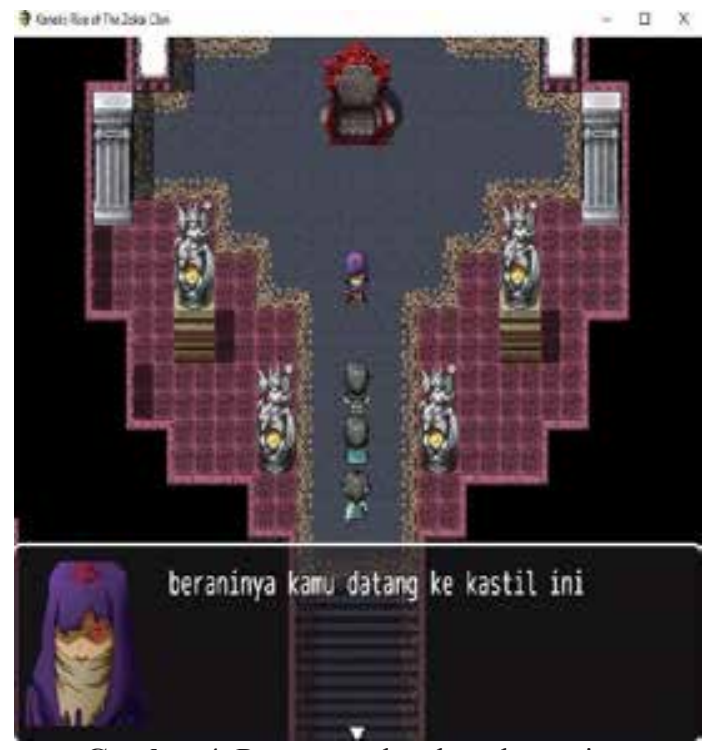

Gambar 4. Rancangan karakter dan sprite

\section{IV.HASIL PENGUJIAN}

Tahapan ini dilakukan pengujian sistem untuk memeriksa apakah sistem yang dihasilkan dapat dijalankan sesuai dengan fungsi serta tujuan awal. Pengujian sistem dengan menggunakan black box test bertujuan untuk mengetahui kesalahankesalahan atau kekurangan sistem yang ada pada aplikasi. Sedangkan uji statistic bertujuan untuk mengetahui apakah calon pengguna bisa menerima aplikasi yang akan digunakan, dengan berdasarkan parameter uji. Hasil pengujian a testing terlihat pada gambar 6 . 


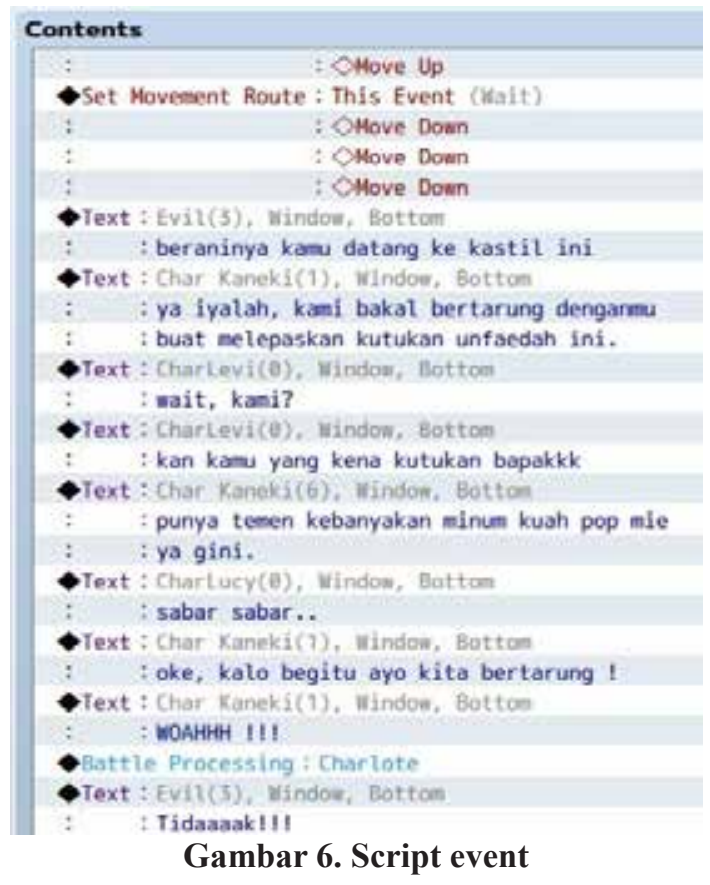

Selanjutnya adalah hasil pengujian terhadap 36 responden. Instrument pengujian adalah pertanyaan atau kuisioner (Rais, 2017). Adapun parameter pengujian adalah (1) Desain yang terdiri dari musik, suara, dan warna (2) Pesan Moral (3) Alur Cerita. Pengujian ini dilakukan untuk mengukur kelayakan game yang telah dikembangkan. Jumlah responden adalah 36 yang diambil secara acak dan 6 responden tidak mengisi instrument sehingga respon rate sebesr 99.8\%. Hasil pengujian terlihat pada Tabel. 1.

Tabel . 1

Hasi pengujian secara random terhadap 36 responden

\begin{tabular}{lcccc}
\hline Parameter & $\begin{array}{c}\text { Kuran } \\
\text { g }\end{array}$ & Cukup & Baik & $\begin{array}{c}\text { Sangat } \\
\text { Baik }\end{array}$ \\
\hline Desain & $16.7 \%$ & $17.5 \%$ & $42.5 \%$ & $23.0 \%$ \\
\hline $\begin{array}{l}\text { Alur } \\
\text { Cerita }\end{array}$ & $16.7 \%$ & $19.0 \%$ & $44.3 \%$ & $19.70 \%$ \\
\hline $\begin{array}{l}\text { Pesan } \\
\text { Moral }\end{array}$ & $11.0 \%$ & $18.7 \%$ & $56.3 \%$ & $24.70 \%$ \\
\hline
\end{tabular}

Tabel. 1 memperlihatkan hasil pengujian game, dan hasilnya adalah sebanyak $42.5 \%$ responden menyatakan bahwa dari sisi desain pengembangan dianggap baik. Sedangkan $44.3 \%$ responden menyatakan game memiliki alur cerita yang baik. Dan $56.3 \%$ responden menyatakan bahwa game Rise of The Zokai Clan menggunakan RPG Maker MV memiliki pesan moral yang baik.

\section{KESIMPULAN}

Berdasarkan hasil pembahasan tentang pengembangan game ini, maka dapat ditarik kesimpulan bahwa:

1. Hasil pengujian menggunakan $\beta$ testing adalah sebanyak $42.5 \%$ responden menyatakan bahwa dari sisi desain pengembangan dianggap baik. Sedangkan $44.3 \%$ responden menyatakan game memiliki alur cerita yang baik. Dan 56.3\% responden menyatakan bahwa game Rise of The Zokai Clan menggunakan RPG Maker MV memiliki pesan moral yang baik.

2. Tahapan pengembangan dari sisi gambar, suara, sistem, dengan menambahkan database image, sound effects, background music, animation, movie, tileset menggunakan RPG Maker MV dianggap baik dan sudah cukup baik.

\section{REFERENCES}

[1] S. Mulyatun, SN Wahyuni. " Studi Deskriptif Pola Pemanfaatan Free Wi-Fi Berdasarkan Konten Yang Diakses Pada Mahasiswa STMIK AMIKOM Yogyakarta" Jurnal DASI. Vol 17, No 2. 2016

[2] SN Wahyuni FW. Wibowo, " Internet Usage Pattern in Entrepreneurship-Based XYZ IT Private University. Advanced Science Letters, Volume 24, Number 4, pp. 26512654(4). 2018.

[3] ST. Galih, AP. Susanto. "Rancang Bangun Game College Story Menggunakan Perangkat Lunak RPG Maker VX". Majalah Ilmiah Informatika Vol 1. No 1. 2013

[4] MIT. Saputra \& H. Al Fatta, "Pembuatan Game RPG "Perjalanan Rio" Menggunakan RPG Maker VX ACE" http://repository.atmaluhur.ac.id//handle/123 456789/1445. 2015

[5] GDK. Wardhana. " Aplikasi Game RPG Bharatayudha区 Menggunakan Engine RPG Maker VX. http://eprints.upnyk.ac.id/id/eprint/5937 .2015 .

[6] S. Machmud, I. Sidharta. "Business Models for SMEs in Bandung: Swot Analysis". Jurnal Ekonomi Bisnis dan Enterpreneure. ISSN.2443-0633. Vol. 8. No. 1. 